\section{Immunoexpression of HIF- $1 \alpha$ and VEGF in Periodontal Disease and Healthy Gingival Tissues}

Roseane Carvalho Vasconcelos ${ }^{1}$, Antônio de Lisboa Lopes Costaํㅜ, Roseana de Almeida Freitas ${ }^{1}$, Bruna Aguiar do Amaral Bezerra ${ }^{1}$, Bruna Rafaela Martins dos Santos ${ }^{2}$, Leão Pereira Pinto ${ }^{1}$, Bruno César de Vasconcelos Gurgel ${ }^{1}$

\author{
'Department of Dentistry, \\ Postgraduate Program, Oral Pathology, \\ UFRN - Universidade Federal do Rio \\ Grande do Norte, Natal, RN, Brazil \\ ${ }^{2}$ Department of Dentistry, UERN \\ - Universidade do Estado do Rio \\ Grande do Norte, RN, Caicó, Brazil
}

Correspondence: Roseane Carvalho Vasconcelos, Av. Senador Salgado Filho, 1787, Lagoa Nova, 59056-000 Natal, RN, Brasil. Tel: +55-84-32154138. e-mail: r.roseane@hotmail.com

\begin{abstract}
Hypoxia-inducible factor 1 alpha (HIF-1 $\alpha$ ) and vascular endothelial growth factor (VEGF) are proteins that stimulate the proliferation and migration of endothelial cells. These proteins have been described in many pathologic and inflammatory conditions, but their involvement in the development of periodontitis has not been thoroughly investigated. This study compared the immunohistochemical expression of these proteins, involved in angiogenesis and hypoxia, by imunnostained inflammatory and endothelial cells in periodontal disease and healthy gingival tissues. Gingival tissue samples were divided as follows: 30 samples with chronic periodontitis, 30 with chronic gingivitis, and 30 of healthy gingiva. Results were analyzed statistically by the Kruskal-Wallis, Mann-Whitney and Spearman correlation tests $(p=0.01)$. Inflammatory and endothelial cells were found to express these proteins. Periodontitis showed median percentage of HIF- $1 \alpha$-positive cells of $39.6 \%, 22.0 \%$ in cases of gingivitis and $0.9 \%$ in the healthy gingiva group $(p=0.001)$. For VEGF, median percentage of immunopositive cells was $68.7 \%$ for periodontitis, $66.1 \%$ in cases for gingivitis, and $19.2 \%$ for healthy gingival specimens $(p<0.001)$. Significant correlation between VEGF and HIF- $1 \alpha$ was also observed in healthy gingiva $(p<0.001)$. The increased expression of HIF- $1 \alpha$ and VEGF in periodontitis, compared to gingivitis and healthy gingiva, suggests possible activation of the HIF-1 $\alpha$ pathway in advanced periodontal disease. The correlation between HIF- $1 \alpha$ and VEGF expression in healthy gingiva suggests a physiological function for these proteins in conditions of homeostasis. In periodontal disease, HIF- $1 \alpha$ and VEGF expression may be regulated by other factors, in addition to hypoxia, such as bacterial endotoxins and inflammatory cytokines.
\end{abstract}

\author{
Key Words: hypoxia-inducible \\ factor alpha subunit, vascular \\ endothelial growth factor, \\ periodontal disease, health \\ tissue. Immunohistochemistry.
}

\section{Introduction}

Periodontal disease is a complex inflammatory condition that affects the tooth-supporting tissues, as a result of infection with anaerobic Gram-negative bacteria. The immune response of the host to these bacteria can lead to progression of the disease and the consequent destruction of soft tissues and alveolar bone resorption $(1,2)$. Several bacterial species express potent virulence factors, such as lipopolysaccharides (LPS), which induce the release of host inflammatory mediators, including prostaglandins and interleukins (IL) that are involved in periodontal breakdown (3).

In periodontitis, particularly, the infiltration of inflammatory cells causes endothelial damage and microcirculatory failure, resulting in decreased oxygen tension (4). This condition, as well as the activity of cytokines and growth factors such as TGF- $\alpha$, TGF- $\beta$, PDGF, FGF, PGE, IL1, IL-6 and IL-8 and endotoxins, stimulates the production of vascular endothelial growth factor (VEGF), which is one of the most important proangiogenic factors (5). VEGF is secreted by mesenchymal cells and is recognized by specific receptors present on vascular endothelial cells (6). In addition, this factor possesses mitogenic activity, regulates endothelial cell migration and vascular permeability, and induces the expression of antiapoptotic proteins in these cells. VEGF is the most important factor involved in physiological and pathological neovascularization and an increased expression of this protein has been demonstrated in patients with periodontal disease $(7,8)$.

One of the main factors stimulating the expression of VEGF is hypoxia-inducible factor 1 alpha (HIF-1 $\alpha$ ), an important nuclear transcription factor found in mammalian cells $(4,9)$. HIF- $1 \alpha$ is regulated by oxygen tension, with rapid degradation of this protein under normoxic conditions and stabilization in the presence of hypoxia. In contrast, the beta subunit is expressed constitutively $(10,11)$. Under conditions of normoxia, HIF-1 $\alpha$ is degraded by an enzymatic system that involves the hydroxylation of specific amino acids (proline) by prolyl-hydroxylase. This hydroxylation permits the recognition of the molecule by specific proteins, an event that culminates in the degradation of HIF- $1 \alpha$ by the ubiquitin-proteasome system $(6,9)$. This system is inhibited under conditions of reduced oxygen tension, favoring the activation of HIF- $1 \alpha$ and the consequent transcription of 
various genes whose proteins are involved in homeostatic, physiological and pathological mechanisms, including genes that encode erythropoietin, transferrin, endothelin, hemoxygenase, and VEGF (11).

$\mathrm{Ng}$ et al. (4) studied healthy gingival and periodontitis specimens and observed increased immunoexpression of VEGF and HIF- $1 \alpha$ in periodontal pockets, when compared to healthy gingiva. These findings suggest the possible involvement of these proteins in the regulation of angiogenesis, disease progression, and tissue destruction. Few studies have investigated the expression of HIF- $1 \alpha$ in periodontal diseases and the correlation between VEGF and HIF- $1 \alpha(4,12,13)$. However, these previous studies were performed with cells from periodontal ligament cultivated in vitro (13). Golz et al. (12) utilized only 3 cases and $\mathrm{Ng}$ et al. (4) used samples from periodontitis and healthy gingiva. Therefore, the objective of the present study was to analyze the expression of these proteins in gingivitis, periodontitis and healthy gingiva in order to know if there is a higher immunoexpression of HIF- $1 \alpha$ and VEGF in diseased tissues and to have a better comprehension of these proteins on pathogenesis of periodontal diseases.

\section{Material and Methods}

The study was approved by the Ethics Committee of the Federal University of Rio Grande do Norte (Process \#332/2011). Thirty samples of chronic periodontitis (probing pocket depth $>4 \mathrm{~mm}$, clinical attachment level $\geq 3 \mathrm{~mm}$ and bleeding on probing), 30 samples of chronic gingivitis (bleeding on probing, no attachment loss), and 30 samples of healthy gingiva (no signs of inflammation, absence of bleeding on probing and no attachment loss) were selected for this study following criteria performed by American Academy of Periodontology (14). The power of the sample was calculated considering the percentage of HIF- $1 \alpha$ for periodontitis and healthy gingiva, and $95 \%$ confidence interval. The results showed a power of $94.9 \%$.

Specimens were stored at Pathological Anatomy Service, Department of Dentistry, at Federal University of Rio Grande do Norte. All specimens were obtained from systemically healthy patients who underwent to periodontal surgery from May/2011 to July/2013. Those specimens should have a clinical diagnosis of chronic gingivitis and periodontitis, and healthy gingiva. All specimens were submitted to immunohistochemical analysis of VEGF and HIF- $1 \alpha$.

\section{Immunohistochemistry}

The immunoperoxidase method, employing a dextran polymer-based technique, and the streptavidin-biotin LSAB method (Advance ${ }^{\mathrm{TM}}$ HRP, Dako, Carpinteria, CA, USA) were used. Briefly, tissue samples $(3 \mu \mathrm{m})$ were deparaffinized and immersed in $0.3 \%$ hydrogen peroxide for the blockage of endogenous peroxidase. Antigen retrieval of the anti-VEGF antibody (SC-7269; Santa Cruz Biotechnology, Santa Cruz, CA, USA) was achieved using $0.1 \%$ trypsin, $\mathrm{pH} 7.9,37^{\circ} \mathrm{C}$, $60 \mathrm{~min}$, overnight for $18 \mathrm{~h}$ (1:500). For the anti-HIF-1 $\alpha$ antibody (SC-53546; Santa Cruz Biotechnology), antigen retrieval was carried out with citrate, $\mathrm{pH}$ 6.0, Pascal, 121 ${ }^{\circ} \mathrm{C}$, 3 min, overnight for $18 \mathrm{~h}$ (1:150 dilution). Peroxidase activity was visualized by incubation of the specimens in diaminobenzidine as chromogen. Colon adenocarcinoma specimens served as a positive control. Negative control included replacement of monoclonal antibody with an irrelevant antibody of the same class (nonimmunized mouse $\lg \mathrm{G}$ ).

\section{Evaluation of Immunoexpression}

The immunoexpression of VEGF and HIF- $1 \alpha$ was evaluated in the connective tissue of periodontitis, gingivitis and healthy gingival specimens. Immunopositive inflammatory and endothelial cells were analyzed quantitatively, irrespective of brown color intensity. Five fields containing the largest number of immunostained cells were identified in the tissue specimens under a light microscope at 100x magnification. Subsequently, the same fields were photographed under a Nikon Eclipse E200 light microscope equipped with a digital camera at 400x magnification. The images were captured using Infinity Analyze software (Lumenera Corporation, Ottawa, Ontario, Canada) and analyzed using Image J image-analysis software (U. S. National Institutes of Health, Bethesda, MD, USA). The number of inflammatory and endothelial cells (positive and negative) was counted in each field and the percentage of positive cells was calculated for each case by a blinded and calibrated examiner (intraclass correlation coefficient; ICC $=0.86$ ).

\section{Statistical Analysis}

Results were analyzed statistically using the Statistical Package for the Social Sciences (SPSS 17.0). The immunoexpressions of VEGF and HIF- $1 \alpha$ were compared between groups using the nonparametric Kruskal-Wallis test. The Mann Whitney test was used to identify statistical differences between groups. The $95 \%$ confidence interval was calculated and a $p$ value $<0.05$ was considered to be significant for all tests.

\section{Results}

Seventy-seven specimens were collected from female patients and 13 from male patients. The mean age of all groups was $35.56 \pm 14.96$ years (periodontitis: $47.70 \pm 10.83$ years; gingivitis: $28.83 \pm 12.06$ years; healthy gingiva: $26.06 \pm 8.21$ years). Morphological analyses showed the presence of a mild to intense inflammatory infiltrate in the 
lamina propria of all specimens analyzed. The inflammatory infiltrate was diffuse and intense in most cases of periodontitis (83.33\%); most cases of gingivitis (86.67\%) exhibited a moderate to intense infiltrate involving the middle third of the specimen. Samples of healthy gingiva presented, in $83.33 \%$ of cases, mild inflammatory infiltrate in the subepithelial area.

Biomarkers showed similarity for cellular immunolocalization and pattern of expression in all specimens. The immunoexpression for HIF- $1 \alpha$ and VEGF was observed in connective tissue, in chronic and acute inflammatory cells as well as in endothelial cells. Both proteins showed nuclear and cytoplasmic immunoreactivity and a diffuse pattern of expression. Blood vessels also showed positivity when they were present in the specimens.

Analysis of the expressions of HIF- $1 \alpha$ and VEGF revealed nuclear and cytoplasmic immunoreactivity in the inflammatory and endothelial cells.

The median percentage of VEGF immunopositive cells showed significant difference in VEGF immunoexpression among gingivitis, periodontitis and healthy gingival specimens (Kruskal-Wallis test, $\mathrm{p}<0.001$ ) (Table 1 and Fig. 1). Mann-Whitney test showed statistically significant differences between periodontitis and healthy gingiva ( $p$ $=0.001)$ as well as between gingivitis and healthy gingiva $(p<0.001)$ (Table 2).

The median percentage of HIF-1 $\alpha$-positive cells showed significant difference in HIF-1 $\alpha$ immunoexpression observed among gingivitis, periodontitis and healthy gingival specimens (Kruskal-Wallis test, $p=0.001$ ) (Table 1 and Fig. 2). Mann-Whitney test showed statistically significant differences between periodontitis and healthy gingiva $(p<0.001)$ as well as between gingivitis and healthy gingiva $(p=0.005)$ (Table 2$)$.

Correlation analysis between the percentage of immunopositivity for HIF-1 $\alpha$ and VEGF revealed positive correlation in healthy gingival specimens. (Spearman's correlation test, $r=0.74 ; p<0.001$ ) (Table 3 ).

\section{Discussion}

The constant challenge of periodontal tissues by potentially pathogenic microorganisms can trigger a response to infection and its virulence products even in clinically healthy patients. This response can result in a hypoxic tissue and inflammatory mediators against pathogenic factors. Elimination of microorganisms depends on innate and adaptive immunologic mechanisms against any infection $(15,16)$. The adaptive response from mammal cells in low concentrations of oxygen inside tissues is mediated by HIF -1]. Its expression can regulates genes implicated on metabolism control, angiogenesis apoptosis and cellular stress. VEGF is one of these genes that has been implicated in disease progression due to its role in the regulation of microcirculation in pathological processes

Table 1. Evaluation of the expression of positive inflammatory and endothelial cells with HIF-1 $\alpha$ and VEGF in periodontitis (P), gingivitis (G) and healthy gingiva (H) (Kruskal-Wallis test)

\begin{tabular}{lcccccc}
\hline Condition & $\mathrm{n}$ & Median & Q25-Q75 & $\begin{array}{c}\text { Mean } \\
\text { Rank }\end{array}$ & KW & $\mathrm{p}$ \\
\hline VEGF & & & & & & \\
$\mathrm{P}$ & 30 & $68.7^{\mathrm{a}}$ & $37.3-81.8$ & 52.9 & 22.4 & $<0.001$ \\
$\mathrm{G}$ & 30 & $66.1^{\mathrm{a}}$ & $50.5-80.9$ & 56.3 & & \\
$\mathrm{H}$ & 30 & $19.2^{\mathrm{b}}$ & $0.0-46.8$ & 27.2 & & \\
HIF-1 $\alpha$ & & & & & & \\
$\mathrm{P}$ & 30 & $39.6^{\mathrm{a}}$ & $6.4-77.0$ & 55.7 & 14.4 & 0.001 \\
$\mathrm{G}$ & 30 & $22.0^{\mathrm{a}}$ & $6.4-5.0$ & 49.5 & & \\
$\mathrm{H}$ & 30 & $0.85^{\mathrm{b}}$ & $0.0-34.5$ & 31.3 & & \\
\hline
\end{tabular}

Different letters indicate statistically significant difference.
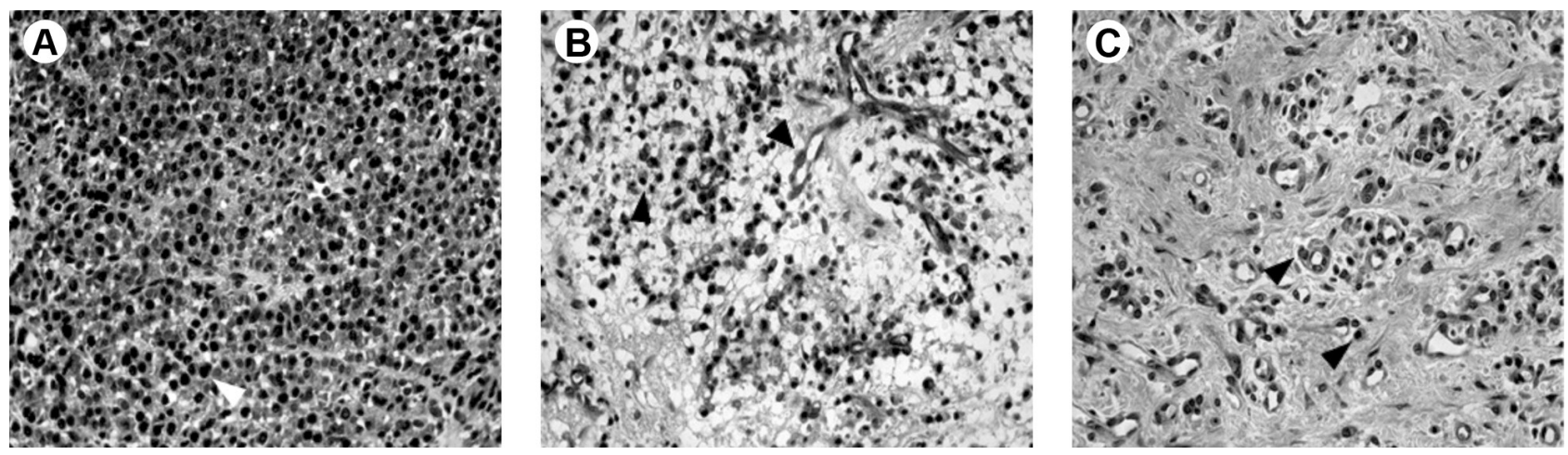

Figure 1. Photomicrographs showing immunostaining for VEGF in samples of periodontitis, gingivitis and healthy gingiva. A: Chronic periodontitis: intense VEGF immunostaining in inflammatory cells (white arrow). B: Chronic gingivitis: VEGF immunostaining in inflammatory cells and endothelial cells (black arrows). C: Healthy gingiva: VEGF immunostaining in inflammatory cells and endothelial cells (black arrows) (LSAB, 400×). 
$(8,15-17)$. In addition, VEGF is involved in homeostasis and wound healing (7). However, the role of this growth factor in periodontal tissues is not fully understood (8).

In the present study, a high percentage of VEGF immunopositive cells were observed in cases of periodontitis and gingivitis. In contrast, the expression of this protein reached lower levels in healthy sites, with significant difference between groups. These outcomes suggest that VEGF represents and important factor on initiation and progression from gingivitis to periodontitis. It has been associated with the severity of inflammation because of the capacity to promote vascular expansion and angiogenesis. Additionally, previous evidences have reported the role of VEGF on osteoblasts and osteoclasts recruitment what can act on regulation of osseous homeostasis (18).

Pradeep et al. (8) observed higher concentrations of VEGF in the crevicular fluid of patients with chronic periodontitis. On the other hand, Cetinkaya et al. (7) found a higher expression of VEGF during the healing stage of

Table 2. Expression of positive inflammatory and endothelial cells$$
\text { sing }
$$
with HIF-1 $\alpha$ and VEGF between periodontitis (P), gingivitis (G) and healthy gingiva (H) (Mann-Whitney test)

\begin{tabular}{|c|c|c|}
\hline Condition (n) & $\mathrm{U}$ & $\mathrm{p}$ \\
\hline \multicolumn{3}{|l|}{ VEGF } \\
\hline P (30) X G (30) & 441.0 & 0.89 \\
\hline P (30) X H (30) & 217.0 & 0.001 \\
\hline G (30) X H (30) & 134.0 & $<0.001$ \\
\hline
\end{tabular}

HIF- $1 \alpha$

\begin{tabular}{lcc}
$P(30) X$ G (30) & 381.5 & 0.31 \\
P (30) X H (30) & 211.5 & $<0.001$ \\
G (30) X H (30) & 261.5 & 0.005 \\
\hline
\end{tabular}

periodontal disease, when compared to the destruction stage. Other studies $(1,19)$ reported higher concentrations of VEGF in gingival fluid collected from healthy sites. In a study involving diabetic patients and systemically healthy subjects, Unlü et al. (20) observed no significant difference in VEGF immunoexpression between cases of healthy gingiva and periodontitis in the group without systemic diseases. These results and those reported by Pradeep et al. (8) and Cetinkaya et al. (7) indicate conflicting roles of VEGF in the pathogenesis of periodontal diseases, with this factor being involved in both the progression of the disease and tissue homeostasis.

One common feature in cases of bacterial infection is the state of hypoxia caused by tissue inflammation, which results in endothelial damage and edema, causing microcirculatory failure and reducing oxygen supply. The adaptive response of mammalian cells to oxygen depletion stress in inflamed and infected lesions is coordinated by HIF- $1 \alpha$. This protein can be induced by inflammatory cytokines and bacterial products even under conditions of normoxia (21). The present study investigated the expression of HIF- $1 \alpha$ in healthy and diseased periodontal tissues and

Table 3 Parameters used for the calculation of Spearman's correlation (r) test for the evaluation of the correlation between HIF- $1 \alpha$ and VEGF in periodontitis $(\mathrm{P})$, gingivitis $(\mathrm{G})$ and healthy gingiva $(\mathrm{H})$

\begin{tabular}{lccc}
\hline Condition & $\mathrm{n}$ & $\mathrm{r}$ & $\mathrm{p}$ \\
\hline $\mathrm{P}$ & 30 & 0.25 & 0.18 \\
HIF-1 $\alpha$ X VEGF & & & \\
$\mathrm{G}$ & & & \\
HIF-1 $\alpha$ X VEGF & 30 & 0.21 & 0.25 \\
$\mathrm{H}$ & & & \\
HIF-1 $\alpha$ X VEGF & 30 & 0.74 & $<0.001$ \\
\hline
\end{tabular}
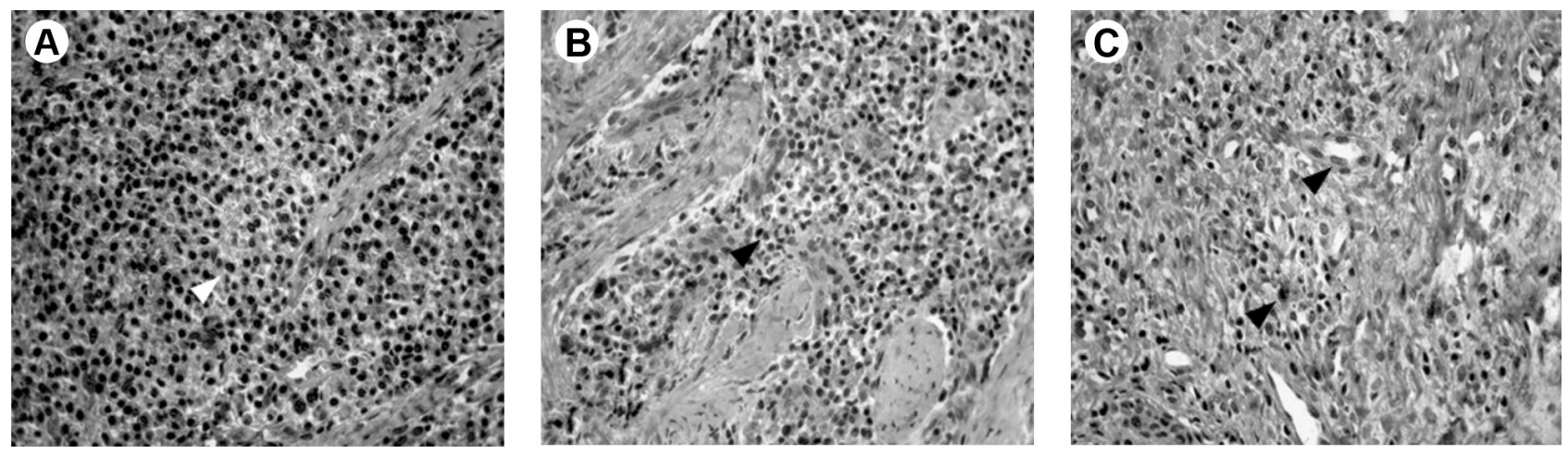

Figure 2. Photomicrographs showing immunostaining for HIF-1 $\alpha$ in samples of periodontitis, gingivitis and healthy gingiva. A: Chronic periodontitis: intense HIF-1 $\alpha$ immunostaining in inflammatory cells (white arrow). B: Chronic gingivitis: HIF-1 $\alpha$ immunostaining in inflammatory cells and endothelial cells (black arrows). C: Healthy gingiva: HIF-1 $\alpha$ immunostaining in inflammatory cells and endothelial cells (black arrows) (Advance, 400×). 
its correlation with VEGF expression.

Results showed that the immunoexpression of HIF-1 $\alpha$ was higher in periodontitis than in gingivitis and healthy gingiva, with statistically significant difference. These findings agree with those of $\mathrm{Ng}$ et al. (4) who observed significantly higher immunoreactivity to HIF- $1 \alpha$ in inflammatory and endothelial cells of periodontitis and gingivitis tissues, compared to healthy tissues.

Although most studies investigating the regulation of HIF- $1 \alpha$ indicate that this protein is activated by hypoxia, Hellwig-Burgel et al. (22) suggested that HIF- $1 \alpha$ could also be induced by proinflammatory cytokines such as IL- $1 \beta$ and TNF- $\alpha$. Furthermore, it has been demonstrated that TNF- $\alpha$ can induce the expression of HIF- $1 \alpha$ in inflammatory cells and that this nuclear factor is directly involved in the regulation of VEGF expression at inflammatory sites $(21,23)$.

The involvement of HIF- $1 \alpha$ in the survival of activated T lymphocytes has also been reported (24). Due to the inhibition of apoptotic processes, these cells remained for a longer time at inflammatory sites, delaying the resolution of the condition. Heavy lymphocytic infiltrate was observed in periodontal tissues, which could be attributed to the HIF- $1 \alpha$ overexpression observed in these specimens.

Golz et al. (12) tested HIF-1 $\alpha$ activation of in periodontal ligament cells of Porphyromonas gingivalis, and observed a significant increase in HIF-1 $\alpha$ mRNA after 4 hours incubation under hypoxic conditions and a more pronounced expression (an almost 30-fold increase) after stimulation with LPS under these conditions. Li et al. (13) studied HIF-1 $\alpha$ expression in human gingival fibroblast cultures by immunoprecipitation and immunoblotting. These authors found that E. coli LPS, in combination with hypoxia, enhances the activation of HIF- $1 \alpha$, with the observation of a two-fold increase when compared to the state of hypoxia alone. Another study (4) using immunohistochemistry showed that HIF-1 $\alpha$ was highly expressed in periodontitis tissues than in healthy tissues, particularly in areas of intense inflammatory infiltration. Moreover, HIF- $1 \alpha$ and VEGF can be induced by bacterial LPS in human gingival fibroblasts under both normoxic and hypoxic conditions. In this respect, Li et al. (13) measured transcription levels of one of its products, VEGF-A. The PCR results showed increased expression of VEGF-A mRNA under the influence of LPS in normoxia and hypoxia, suggesting that HIF- $1 \alpha$ plays a regulatory role in inflammatory processes and in periodontal tissue homeostasis.

The results showed positive correlation $(p<0.001)$ between these two proteins in healthy gingiva what could suggest that HIF- $1 \alpha$ can influence the activation of VEGF. It could be related with constitutive expression of HIF -1 $\square$ and demonstrate a physiological role of these proteins on tissue homeostasis. Furthermore, periodontal tissues are constantly being challenged by periodontopathogenic microbiota, promoting the release of proinflammatory mediators, such as IL- $1 \beta$ and TNF- $\alpha$, which can induce the transcription of VEGF, even under normoxic conditions.

HIF-1 $\alpha$ participates in several cellular processes such as angiogenesis, energy metabolism, nutrient transport, and apoptosis (11). This transcription factor is activated in response to tissue inflammation, with implications for the development of different infectious and ischemic diseases, including periodontal diseases $(11,13)$. However, further studies investigating the participation of events, in addition to hypoxia, in the activation of HIF- $1 \alpha$, such as the action of bacterial endotoxins, are needed to better understand the role of this molecule in the development of periodontal diseases.

One limitation of this cross-sectional study is that cannot be affirmed that the activation of HIF- $\alpha$ and VEGF precede, in a temporal and causal way, the occurrence of periodontal disease. This study analyzed a specific sample with no intention to generalize for the entire population (25).

In conclusion, the increased expressions of HIF- $1 \alpha$ and VEGF in periodontitis, when compared to gingivitis and healthy gingiva, suggests a possible activation and involvement of these proteins in advanced periodontal disease, but it is difficult to determine the extent of the participation of HIF $-1 \alpha$ and VEGF in pathogenesis. In periodontal disease, VEGF expression may be regulated by other factors, in addition to hypoxia, such as bacterial endotoxins and inflammatory cytokines.

\section{Resumo}

0 fator induzivel por hipóxia 1 alfa (HIF-1 $\alpha$ ) e o fator de crescimento endotelial vascular (VEGF) são proteinas que estimulam a proliferação e a migração de células endoteliais. Estas proteínas têm sido descritas em muitas condições patológicas e inflamatórias, mas o envolvimento dessas no desenvolvimento de periodontite não foi completamente investigado. Este estudo comparou a expressão imunohistoquímica destas proteínas, envolvidas na angiogênese e hipóxia, na doença periodontal e em tecidos gengivais saudáveis por meio de contagem de células inflamatórias e endoteliais imunomarcadas. As amostras de tecido gengival foram divididas da seguinte forma: 30 amostras com periodontite crônica, 30 com gengivite crônica e 30 de gengiva saudável. Os resultados foram analisados estatisticamente pelos testes de Kruskal-Wallis e Mann-Whitney $(\alpha=0.01)$. As células inflamatórias e endoteliais foram positivas para estas proteinas. A porcentagem média de células positivas para HIF-1 $\alpha$ foi de $39,6 \%$ nos casos de periodontite, $22,0 \%$ nos casos de gengivite e de $0,9 \%$ no grupo de gengiva saudável $(p=0,001)$. A porcentagem média de células imunopositivas para o VEGF foi de $68,7 \%$ nos casos de periodontite, $66,1 \%$ nos casos de gengivite, e 19,2\% em espécimes gengivais saudáveis $(p<0,001)$. Correlação significativa entre o VEGF e HIF-1 $\alpha$ foi observada em gengival. A expressão elevada do HIF-1 $\alpha$ e VEGF em periodontite, comparada a gengivite e gengiva saudável, sugere ativação da via do HIF-1 $\alpha$, na doença periodontal avançada. A correlação entre o HIF-1 $\alpha$ e expressão de VEGF na gengiva saudável, sugere uma função fisiológica para estas proteínas em condições de homeostase. Na doença periodontal, a expressão de HIF-1 $\alpha$ e VEGF pode ser regulada por outros fatores, além da hipóxia, tais como endotoxinas bacterianas e citocinas inflamatórias. 


\section{References}

1. Booth V, Young S, Cruchley A, Taichman NS, Paleolog E. Vascular endothelial growth factor in human periodontal disease. J Periodontol 1998;33:491-499.

2. Lins RDAU, Alves PMA, Godoy GP, Silveira, EJDS, Queiroz LMG, Freitas RA. Immunohistochemical evaluation of CD25+ cell expression in the progression of periodontal disease. Braz Dent J 2012;23:322-327.

3. Wara-aswapati N, Surarit R, Chayasadom A, Boch JA, Pitiphat W. RANKL upregulation associated with periodontitis and Porphyromonas gingivalis. J Periodontol 2007;78:1062-1069.

4. Ng KT, Li JP, Ng KM, Tipoe GL, Leung WK, Fung ML. Expression of hypoxia-inducible factor-1 $\alpha$ in human periodontal tissue. J Periodontol 2011;82:136-141.

5. Lee JW, Bae SH, Jeong W, Kim SH, Kim KW. Hypoxia-inducible factor (HIF-1) alpha: its protein stability and biological functions. Exp. Mol. Med 2004;36:1-12.

6. Ratcliffe PJ. HIF-1 and HIF-2: working alone or together in hypoxia? J Clin Invest 2007;117:862-865.

7. Cetinkaya BO, Keles GC, Ayas B, Sakallioglu EE, Acikgoz G. The expression of vascular endothelial growth factor in a rat model at destruction and healing stages of periodontal disease. J Periodontol 2007;78:1129-1135.

8. Pradeep AR, Prapulla DV, Sharma A, Sujatha PB. Gingival crevicular fluid and serum vascular endothelial growth factor: their relationship in periodontal health, disease and after treatment. Cytokine 2011;54:200-204.

9. Semenza GL. Oxygen sensing, homeostasis, and disease. N Engl J Med 2011;365:537-547.

10. Ke Q, Costa, M. Hypoxia-inducible factor-1 (HIF-1). Mol Pharmacol 2006;70:469-480.

11. Schofield CJ, Ratcliffe PJ. Oxygen sensing by HIF hydroxylases. Nat Rev Mol Cell Biol 2004;5:343-354.

12. Gölz L, S. Memmert, Rath-Deschner B, Jäger A, Appel T, Baumgarten G, et al.. Hypoxia and P. gingivalis synergistically induce HIF-1 and NF-B activation in PDL cells and periodontal diseases. Mediators Inflamm 2015;2015:438085.

13. Li JP, Li FY, Xu A, Cheng B, Tsao SW, Fung, ML et al.. Lipopolysaccharide and hypoxia-Induced HIF-1 activation in human gingival fibroblasts. J Periodontol 2012;83:816-824.
14. American Academy of Periodontology. Development of a Classification System for Periodontal Diseases and Conditions. Ann Periodontol 1999; 4:1-6.

15. Trebec-Reynolds DP, Voronov I, Heersche JN, Manolson MF. VEGF-A expression in osteoclasts is regulated by NFkappaB induction of HIF1alpha. J Cell Biochem 2010;110:343-351.

16. Peyssonnaux C, Datta V, Cramer T, Doedens A, Theodorakis EA, Gallo $\mathrm{RL}$, et al.. HIF-1 alpha expression regulates the bactericidal capacity of phagocytes. J Clin Invest 2005;115:1806-1815.

17. Johnson RB, Serio FG, Dai X. Vascular endothelial growth factors and progression of periodontal diseases. J Periodontol 1999;70:848-852.

18. Kranti K, Mani R, Anjana Elizabeth A. Immunoexpression of vascular endothelial growth factor and Ki 67 in human gingival samples: An observational study. Indian Journal of Dentistry 2015; 6: 69-74.

19. Chapple CC, Kumar RK, Hunter N. Vascular remodelling in chronic inflammatory periodontal disease. J Oral Pathol Med 2000;29:500-506.

20. Unlu F, Guneri PG, Hekimgil M, Yesilbek B, Boyacioglu H. Expression of vascular endothelial growth factor in human periodontal tissues: Comparison of healthy and diabetic patients. J Periodontol 2003;74:181-187.

21. Imtiyaz HZ, Simon MC. Hypoxia-inducible factors as essential regulators of inflammation. Curr Top Microbiol Immunol 2010;345:105-120.

22. Hellwig-Bürgel $T$, Rutkowski $K$, Metzen $E$, Fandrey J, Jelkmann W. Interleukin-1 $\beta$ and tumor necrosis factor- $\alpha$ stimulate DNA binding of hypoxia-inducible factor-1. Blood 1999;94:1561-1567.

23. Albina JE, Mastrofrancesco B, Vessella JA, Louis CA, Henry WU. Reichner JS. HIF-1 expression in healing wounds: HIF- $1 \alpha$ induction in primary inflammatory cells by TNF- $\alpha$. Am J Physiol Cell Physiol 2001;281:19711977.

24. Kominsky DJ, Campbell EL, Colgan SP. Metabolic shifts in immunity and inflammation. J Immunol 2010;184:4062-4068.

25. Carlson MDA, Morrison RS. Study design, precision, and validity in observational studies. J Palliat Med 2009; 12:77-82.

Received September 14, 2015 Accepted January 11, 2016 